\title{
Front Matter: Volume 11391
}

, "Front Matter: Volume 11391," Proc. SPIE 11391, Quantum Information Science, Sensing, and Computation XII, 1139101 (10 June 2020); doi: 10.1117/12.2572754

SPIE. Event: SPIE Defense + Commercial Sensing, 2020, Online Only 


\section{PROCEEDINGS OF SPIE}

\section{Quantum Information Science, Sensing, and Computation XII}

Eric Donkor

Michael Hayduk

Editors

27 April - 8 May 2020

Online Only, United States

Sponsored and Published by

SPIE 
The papers in this volume were part of the technical conference cited on the cover and title page. Papers were selected and subject to review by the editors and conference program committee. Some conference presentations may not be available for publication. Additional papers and presentation recordings may be available online in the SPIE Digital Library at SPIEDigitalLibrary.org.

The papers reflect the work and thoughts of the authors and are published herein as submitted. The publisher is not responsible for the validity of the information or for any outcomes resulting from reliance thereon.

Please use the following format to cite material from these proceedings:

Author(s), "Title of Paper," in Quantum Information Science, Sensing, and Computation XII, edited by Eric Donkor, Michael Hayduk, Proceedings of SPIE Vol. 11391 (SPIE, Bellingham, WA, 2020) Sevendigit Article CID Number.

ISSN: 0277-786X

ISSN: 1996-756X (electronic)

ISBN: 9781510635593

ISBN: 9781510635609 (electronic)

Published by

SPIE

P.O. Box 10, Bellingham, Washington 98227-0010 USA

Telephone +1 3606763290 (Pacific Time) · Fax +1 3606471445

SPIE.org

Copyright (c) 2020, Society of Photo-Optical Instrumentation Engineers.

Copying of material in this book for internal or personal use, or for the internal or personal use of specific clients, beyond the fair use provisions granted by the U.S. Copyright Law is authorized by SPIE subject to payment of copying fees. The Transactional Reporting Service base fee for this volume is $\$ 21.00$ per article (or portion thereof), which should be paid directly to the Copyright Clearance Center (CCC), 222 Rosewood Drive, Danvers, MA 01923. Payment may also be made electronically through CCC Online at copyright.com. Other copying for republication, resale, advertising or promotion, or any form of systematic or multiple reproduction of any material in this book is prohibited except with permission in writing from the publisher. The CCC fee code is $0277-$ $786 \mathrm{X} / 20 / \$ 21.00$.

Printed in the United States of America by Curran Associates, Inc., under license from SPIE.

Publication of record for individual papers is online in the SPIE Digital Library.

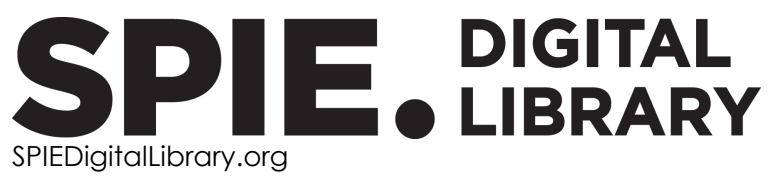

Paper Numbering: Proceedings of SPIE follow an e-First publication model. A unique citation identifier (CID) number is assigned to each article at the time of publication. Utilization of CIDs allows articles to be fully citable as soon as they are published online, and connects the same identifier to all online and print versions of the publication. SPIE uses a seven-digit CID article numbering system structured as follows:

- The first five digits correspond to the SPIE volume number.

- The last two digits indicate publication order within the volume using a Base 36 numbering system employing both numerals and letters. These two-number sets start with $00,01,02,03,04$, 05, 06, 07, 08, 09, OA, OB ... 0Z, followed by 10-1Z, 20-2Z, etc. The CID Number appears on each page of the manuscript. 


\section{Contents}

SESSION 1 QUANTUM COMPUTING I

1139105 Toward mobile free-space optical QKD: characterization of a polarization-based receiver [11391-21]

SESSION 2 QUANTUM COMPUTING II

1139106 Practical numerical integration on NISQ devices [11391-4]

SESSION 3 QUANTUM SENSORS, QUANTUM SYSTEMS

11391 OA Quantum Fisher information matrix of a single qutrit in Xi or cascade configuration [1 1391-8]

$11391 \mathrm{OB} \quad$ A hybrid quantum enabled RBM advantage: convolutional autoencoders for quantum image compression and generative learning [11391-9]

11391 OC GaN laser diodes for quantum sensors and optical atomic clocks [11391-10]

11391 OD Wavefront design for improved performance by entangled systems [1 1391-12]

SESSION 4 QKD, CRYPTOGRAPHY, AND SECURE COMMUNICATION

$113910 G \quad$ A semi-quantum extended B92 protocol and its analysis [11391-15]

\section{SESSION 5 QUANTUM INFORMATION SCIENCE}

113910 Approximate graph spectral decomposition with the Variational Quantum Eigensolver [11391-17]

$113910 \mathrm{~J}$ Quantum central limit theorem and statistical hypothesis testing in discrete quantum walk [11391-18]

$11391 \mathrm{OL}$ Objective function maximization by machine learning for gate-model quantum computers [11391-20] 
Proc. of SPIE Vol. 11391 1139101-4

Downloaded From: https://www.spiedigitallibrary.org/conference-proceedings-of-spie on 26 Apr 2023
Terms of Use: https://www.spiedigitallibrary.org/terms-of-use 